\title{
Stanislav Zhukovsky: an underrated artist
}

\author{
A. Zadoia, I. Syzonenko \\ Alfred Nobel University, Dnipro, Ukraine \\ John Paul II Catholic University of Lublin, Poland \\ Corresponding author. E-mail: zadoya@duan.edu.ua, 9sirena@gmail.com
}

Paper received 09.02.21; Accepted for publication 21.02.21.

\section{https://doi.org/10.31174/SEND-HS2021-249IX44-03}

\begin{abstract}
Stanislav Zhukovsky belongs to a galaxy of talented Polish artists, whose name and whose works have not been properly recognized in modern Poland. A study of his life and works at the end of the 19th - beginning of the 20th centuries demonstrates the great love of this artist for Poland, nature and art. Since the end of the 90s of the last century, a revival of interest in the artist's works has been observed, which is confirmed by an increase in the number of successful sales of paintings by S. Zhukovsky at auctions. If the first auctions were held mainly in the artist's homeland, then in subsequent years the center of trade moved to British auctions of world renown. The analysis showed an increase in the average price of paintings sold, which confirms the investment attractiveness of the paintings of this artist.
\end{abstract}

Keywords: Stanislav Zhukovsky, painting auctions, average auction price of a painting.

Introduction. An amazing feature of the management of the modern world art market is the ability to find genuine masterpieces of fine art, which, due to political, economic, social or some other circumstances, turned out to be "forgotten art" buried in archives, storerooms of museums and galleries, and private collections. The phrase of the Russian writer Mikhail Bulgakov that "manuscripts do not burn" takes on a symbolic meaning to reveal to the world the personality and work of the famous Polish artist Stanislav Yulianovich Zhukovsky (18731944), although a large number of his works burned down in the fire of the Warsaw Uprising in 1944.

S. Zhukovsky was widely known as a master of landscape painting of the late 19th and early 20th centuries, he was gifted with talent. He was able to live his life brightly and diversely, had many passions of which three were the most important: love for Poland, nature, art.

Unfortunately, many works by S. Zhukovsky are not available to a wide range of art connoisseurs in Poland. Most of the best works of the artist are in private collections. A significant number of works are in museums on the territory of the former Soviet Union, where they tend to gather dust in storerooms and are rarely exhibited. And this despite the fact that at art auctions where the artist's works are exhibited, they are most often sold at prices higher than those stated. The painter's canvases belong to the sought-after and highly valued works of art of the late 19th - early 20th centuries, in which you can confidently invest. Therefore, there is a real need to study the creative heritage of Stanislav Zhukovsky in order to form an objective assessment of his contribution to the development of landscape painting of the late 19th - early 20th centuries.

Review of Publications on the Topic. Pre-revolutionary art critics in Russia drew attention to the work of Stanislav Zhukovsky quite early on. His talent, the results of artistic research and methods of creating works in the open air were appreciated by the leading art historians and painters of that time: A. Skalon, V. Stasov, M. Nesterov, S. Glagol and others.

At the beginning of the 60s of the last century in the USSR, after several decades of oblivion, interest in the work of S. Zhukovsky increased again. At that time, Soviet art historians (R. Badin, N. Stankevich, V. Lapshin and others) included him among the leading Russian landscape painters.

Another work that continues the research of Soviet art critics about the legacy of Zhukovsky is the monograph by M. Gorelov entitled "Stanislav Yulianovich Zhukovsky. Life and work 1875-1944" [1]. The content of the publication consists of a main part, divided into 14 chapters, and an informative part. The main goal of the author is to explain the significance of S. Zhukovsky's legacy in the context of his work and its significance for Russian culture in the late 19th - early 20th centuries. On the other hand, the Polish period in the life and work of S. Zhukovsky was described from the point of view of Soviet ideology. Gorelov presented this period of the artist's work as "hesitant and wandering" in his creative search and identification with European painting, describing his work as "decorative and attracting attention." In this spirit, Gorelowski divided Polish artists into progressive and others (according to Gorelov, non-progressive). However, the main drawback of this monograph is the deliberate disregard of objective historical data and the falsification of Polish and European history when describing and assessing the events of 1939-1944, which undoubtedly affects the level of the work in question.

Russian critics of the fine arts believe that $\mathrm{S}$. Zhukovsky is a great Russian artist who continues the best traditions of the Russian national landscape. This statement, which does not correspond to the real trends and directions of the artist's work, appears in all Russian publications devoted to him. The basis of this statement is the fact of S. Zhukovsky's residence since 1892-1923 on the territory of the Russian Empire, in Moscow (but at that time Poland as an independent state did not exist, and most of the territory of Poland was part of the Russian Empire!), although later, according to most of Russian critics, made a fatal mistake and emigrated to Poland. One of them, the Soviet critic N.I. Stankevich, argued that "under the influence of momentary weakness, Zhukovsky made a fateful mistake. In 1923 he left for Warsaw. He broke away from his native roots and with difficulty adapted to a different soil, did not create anything significant" [2, p.45]. Another Soviet art critic V.P. Lapshin shared a similar opinion, who wrote that "everything that he created is for the most part only a continuation of what he did earlier in Russia" [3, p.19-20]. For some reason, these two critics, like other Soviet researchers, did not notice that Zhukovsky first of all returned to his beloved homeland!

The image of the artist, created by Polish art historians in the interwar period, largely determined the level of interest in his work and the perception of Zhukovsky's works by recipients. Famous Warsaw art critics Vladislav Vanki, Felix Richling, Vaclav Husarsky, Stefania Zagorska, Jan Klechinsky and others wrote about Stanislav Zhukovsky's exhibitions of that period. Their opinions and judgments were very diverse and full of contradictions, from a sincere desire to understand and appreciate the artist's paintings to a categorical rejection 
of the artist's creativity and personality.

In 1923, Eligiusz Nevyadomski published the book entitled "Polish Painting of the XIX and XX Centuries", in which Stanislav Zhukovsky joined a group of such Polish artists as N. Weissenhoff, J. Rapacki, T. Ziomek, S. Popovsky, J. Mankovsky other. E. Nevyadomsky presents a short biography of the artist to Polish readers, calling him "an excellent draftsman and a strange colorist". On the other hand, the artist himself belongs to the group of "the best representatives of the Russian landscape" [4]. This opinion should not be surprising, since this work was published in 1923, that is, in the year when the artist left the USSR and returned to Poland.

In the context of the issues discussed in this article, the publication of the art market expert Dr. Monika Bryl, published in a collective work entitled "Alternative Investments: How to Make Money Investing in Art, Brands, Wine, Whiskey and Other Goods" is very interesting. In her opinion, collecting can be combined with investing. In one of the articles of Dr. Monika Bryl, the name of Stanislav Lukovsky appears for the first time. He was listed in the table "Famous artists, favorite and popular in the market" [5]. Interestingly, the Polish landscape is one of the most demanded topics on the art market.

An article by Jerzy Cichovich, legal expert and art collector, contributes greatly to our topic about the underrated artist Stanislav Zhukovsky. Works of art with a documented history have great potential in this collection.

The purpose of the article. The aim of our study is to introduce the verified life history and creative heritage of Stanislav Zhukovsky into the context of contemporary Polish culture and art criticism. In the course of achieving this goal, the analysis of prices and sales of S. Zhukovsky's works at world auctions was carried out as a kind of catalyst for further scientific research of the artist's creative heritage on the part of representatives of the Polish scientific community, the inclusion of museum collections of S. Zhukovsky's works in the context of contemporary exhibition activities of Polish art museums.

Materials and methods. The main source of information for writing the article was a monographic study, articles and other materials on the study of S. Zhukovsky's creativity, published in domestic and foreign publications.

A separate group of source materials is archival materials studied during the museum survey and search for the collection of the artist's works in Polish museums: The National Museum in Warsaw, the National Museum in Krakow; Ukraine: Dnepropetrovsk Art Museum (Dnipro), Odessa Art Museum (Odessa), Sumy N. Onatsky Art Museum (Sumy), Kharkiv Art Museum (Kharkiv), Kyiv Art Museum "Art Gallery" (Kyiv), Russia: Central State Archives of Literature and Art, PGT (Moscow).

To estimate the value of Zhukovsky's works, materials from various auctions were analyzed at which the artist's paintings were exhibited. These auctions spanned over 120 years, from the first auctions in Moscow in 1896 to the last auctions in Poland in 2019. The study also used materials from well-known auction houses in Germany, Great Britain, Poland, Ukraine and other countries. In some cases, it was possible for the first time to compare the rating given by the author of the painting (at the first exhibitions), the rating of the auction organizers and the final price received after the auction.

Taking into account such a long period and the variety of prices and currencies (from the Tsarist rubles of Russia to the modern EU currency - the euro), in order to be as reliable and comparable as possible, various methods are used to represent and transform these indicators. used, inter alia, the method of discounted cash flows, the method of translation into other units of value. In addition, the work uses a comparative method to present research results in the form of tables and diagrams.

The results of the study. S. Zhukovsky's paintings can be seen not only in Poland, Russia, Belarus, but also in 11 countries of the world. Thanks to the management activities of well-known auction houses in Europe and America, the work of Stanislav Zhukovsky is experiencing its new discovery and popularity - it has become a subject of great interest both to owners and managers of auction houses, as well as historians and critics of fine arts, collectors.

Auctions for the sale of paintings by S. Zhukovsky were held at the end of the 19th century. The first information that has been preserved in the archives relates to an auction held by the Moscow Society of Art Lovers on March 17, 1896 (Table 1). 6 paintings by the artist were put up for sale. Unfortunately, there is no information about the results of the auction, so we can judge the value of the paintings by the estimated value of the corresponding lots. As you can see, the estimate ranges from 13 to 42 Russian rubles. Since there is no description of the paintings, it can be assumed that the differentiation of prices is related to their size, and not to artistic value. Most likely, following the practice of that time, the author himself played a decisive role in the assessment, since he was the beneficiary of this auction.

However, for the modern reader, the price expressed in Russian rubles at the end of the 19th century does not mean anything. In order to make the price palpable, let's make the following comparison. In 1890, the average wage of an unskilled worker in Russia was about 25 rubles a month [6]. Since as of January 1, 2019, the average minimum wage in Poland was 2,250 zlotys [7], this amount can be considered an analogue of Russian 25 rubles at the end of the 19th century. In other words, on average, each painting by S. Zhukovsky at the auction was put up at a price that corresponds to the current minimum monthly wage. Of course, by modern standards, this is a very low price for works of famous artists. But one must bear in mind the fact that 23-year-old S. Zhukovsky was just a student at the Moscow School of Painting, Sculpture and Architecture and a novice artist, for whom earning more than five minimum wages at one auction would be a great success.

We see a completely different picture at the exhibition and sale held in Warsaw in February 1932. The paintings displayed there (18 units) are united by a common idea and form a cycle called "Neman". Until 1939, most of this river flowed through Poland. And such a large number of paintings dedicated to this river testifies to the high creative activity of the artist after returning to his homeland (which once again confirms the groundlessness of the assertions of some authors about the erroneousness of this decision by the artist and the negative impact of the move on his work).

The estimated value of the paintings offered for sale ranges from PLN 1,000 to PLN 5,000. It should be noted that Poland in those years (like the whole world) was going through the Great Depression, which greatly affected both its economic situation and cultural life. Therefore, the sale of paintings even at such prices should be considered a real recognition of the talent of their author.

World auctions in the late XX - early XXI century showed 
special attention to the artist's work. According to data presented on various websites, from 1995 to November 2019, paintings by S. Zhukovsky were exhibited 375 times at auctions. There is confirmed information on the effective sales of 212 paintings, which is $57 \%$ of the displayed ones (there are still about 40 positions for which there is no information). If we analyze the dynamics of sales over the years, it is easy to see that the owners of the paintings were very cautious in the late 90s, and the organizers of the auctions were not too optimistic in assessing the cost of the paintings. In 1995, only 4 paintings were sold, but three of them were sold at a price that significantly exceeded the price declared by the organizers. For example, on December 10, 1995 at the auction Agra-Art (Poland) was sold for 7180 euros painting "Forest Landscape" (1914) (Painting, oil / canvas, $63 \times 765 \mathrm{~cm}$ ), the price of which was declared by the organizers of 3433 euros. In 1996 and 1997, all successful auctions for the sale of paintings by $S$. Zhukovsky ended at prices that significantly exceeded those declared by the organizers.

Table 1. - Lifetime auctions of paintings by Stanislav Zhukovsky *

\begin{tabular}{|c|c|c|c|}
\hline Country, auction & Date & Description of the painting & Grade \\
\hline $\begin{array}{l}\text { Russia, Auction in the Moscow } \\
\text { Society of Art Lovers }\end{array}$ & March, 1896 & $\begin{array}{l}\text { After the fire } \\
\text { Sokolniki } \\
\text { By the evening } \\
\text { Village } \\
\text { Manor house } \\
\text { In the spring }\end{array}$ & $\begin{array}{l}21 \text { rub. } \\
42 \text { rub. } \\
23 \text { rub. } \\
23 \text { rub. } \\
16 \text { rub. } \\
13 \text { rub. }\end{array}$ \\
\hline $\begin{array}{l}\text { Poland, Society for the Promo- } \\
\text { tion of Fine Arts in Warsaw } \\
\text { exhibition-sale }\end{array}$ & February, 1932 & $\begin{array}{l}\text { 1. Ice drift on Nemunas. Nightfall } \\
\text { 2. Ice drift on the Nemunas. In the evening } \\
\text { 3. Wind on the Nemunas } \\
\text { 4. Autumn morning on the Nemunas } \\
\text { 5. Forests on the Nemunas } \\
\text { 6. The old alley over the Nemunas } \\
\text { 7. Summer morning. Linden alley } \\
\text { 8. Hepathes on the window. Nemunas overflowing } \\
\text { 9. The banks of the Nemunas. Golden autumn } \\
\text { 10. A cloudy day on the Nemunas } \\
\text { 11. Quiet evening on the Nemunas } \\
\text { 12. Rafts on the Nemunas River. Autumn } \\
\text { 13. Flooded coastal forests of Niemen } \\
\text { 14. Submerged alder and spruce forests across the Niemen } \\
\text { 15. Sunken old oak } 16 \text {. The gloomy mood of the Nemunas } \\
\text { 17. Sandy cliffs of the banks of the Nemunas } \\
\text { 18. The Nemunas spring water }\end{array}$ & $\begin{array}{l}5.000 \mathrm{zł} \\
5.000 \mathrm{zł} \\
5.000 \mathrm{zt} \\
4.000 \mathrm{zł} \\
3.500 \mathrm{zł} \\
2.500 \mathrm{zł} \\
3.000 \mathrm{zł} \\
3.000 \mathrm{zt} \\
2.500 \mathrm{zł} \\
2.000 \mathrm{zt} \\
2000 \mathrm{zt} \\
2.000 \mathrm{zł} \\
1.500 \mathrm{zł} \\
1.500 \mathrm{zł} \\
1.500 \mathrm{zł} \\
1.500 \mathrm{zł} \\
1.000 \mathrm{zł} \\
1.300 \mathrm{zł}\end{array}$ \\
\hline
\end{tabular}

* Sources: Central State Archives of Literature and Art, Moscow, f.660, op.1, un. 1382, d. 5,6, 7,8; Salon1932, Przewodnik nr 71, luty1932, Warszawa1932

It should be noted that during these years the bulk of successful auctions for the sale of paintings by S. Zhukovstky took place in his homeland - in Poland. But gradually other countries are also joining this process. In 1995, three paintings were sold in Poland and one in the UK; in 1996 - 1 in Poland and 2 in Great Britain; in 1997 - 3 in Poland and 1 in Great Britain.

The successes of the early years of modern auctions activated both sellers and buyers. In 1999, 9 paintings were already sold, of which 5 in Poland, 3 in Great Britain and 1 in Ukraine. Gradually, the sales center moves from Polish to British auctions. More and more often, S. Zhukovsky's paintings are sold at the famous Sotheby's and Christie's (United Kingdom) auctions. Of particular note is the role of auctions in the Scandinavian countries (Sweden and Finland), which in many respects contributed to the subsequent approval of $\mathrm{S}$. Zhukovsky's paintings at world auctions.

In the early years, paintings, as a rule, were exhibited for sale, which, in the opinion of their owners, did not have a large market value. That is why the average price of paintings sold did not exceed 5,000 euros. In 2000 alone, the average price was 16,295 euros for the first time. The maximum average cost of sales for the entire study period was reached in 2005 , when it amounted to 55,152 euros (Fig.1).

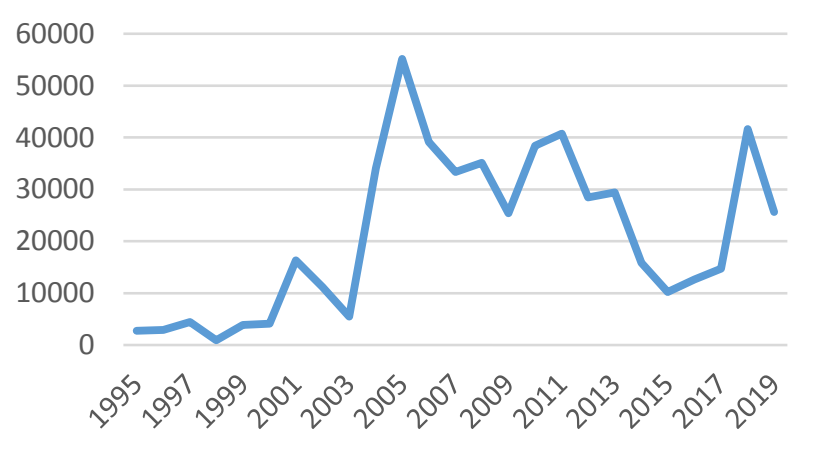

Fig. 3. Dynamics of the average revenue from the sale of one painting by years

However, until 2006, trading took place only at European auctions. On February 25, 2006, a very small watercolor by S. Zhukovstky $(12 \times 7 \mathrm{~cm})$ entitled "View of the Winter Coast" was first sold at an auction by Kaminski \& co. in the United States of America for only 50 euros. But two months later (April 26, 2006) at Sotheby's, United States, S. Zhukovstky's painting "Elegant Interior" (Painting, oil / canvas, 85 x 103.5 $\mathrm{cm}$ ) was sold for 64,552 euros. In general, 2006 was a record year both in terms of the number of paintings by S. Zhukovsky sold at auctions and in terms of total sales proceeds. She reached the amount of 743737 euros!

In subsequent years, there has been a slight decrease in both the number of paintings sold and their total value. There are 
several reasons for this. Firstly, the global financial crisis of 2008-2009 is ready and the protracted depression that followed it had a negative impact on all auctions, as it reduced the opportunities for buyers. Secondly, the active sale of paintings in previous years led to the redistribution of the creative heritage and its settling mainly in private collections, the owners of which are not inclined to sell only the recently acquired. The next cycle of redistribution may be repeated in 10-15 years, when the change of generations of owners begins.

Our analysis showed a close relationship between the number of paintings sold, total revenue and the average cost of one painting. This is also confirmed by calculations of the correlation coefficients between the number of paintings sold, total revenue and the average price of a painting. So, according to our estimates, the correlation coefficient between the number of paintings sold and the total revenue is 0.81 , and between the total revenue and the average price of the painting even 0.86 , which can be regarded as a very high degree of correlation.

Analysis of the auction results allows us to draw another very important conclusion: Stanislav Zhukovsky is a worldrenowned artist. The artist's paintings were sold at auctions in 14 countries of the world located in Europe, America and Asia (Table 2). Most of the paintings were sold at UK auctions (64 paintings). And this is natural, because it is in this country that the most famous art auctions in the world work. The second position is occupied by Poland (45 paintings), which is also quite understandable. After all, it was here that a significant part of the artist's canvases was written and it is this country that rightfully considers him its compatriot. In this regard, the comparison of the results of auctions in the Russian Federation (which sometimes attributes to S. Zhukovsky that he is a
Russian artist), where only 4 paintings were sold in 25 years, is indicative in this regard.

A very significant contribution to the organization of sales of S. Zhukovsky's paintings was made by auctions in the USA, Germany, Austria and France.

Table 2. - Geographic structure of successful auctions for the sale of paintings by S. Zhukovsky for the period from 1995 to 2019

\begin{tabular}{|l|c|c|c|}
\hline \multicolumn{1}{|c|}{ Country } & $\begin{array}{c}\text { Number of } \\
\text { paintings sold } \\
\text { at auctions }\end{array}$ & Country & $\begin{array}{c}\text { Number of } \\
\text { paintings sold } \\
\text { at auctions }\end{array}$ \\
\hline $\begin{array}{l}\text { Great Brit- } \\
\text { ain }\end{array}$ & 64 & Switzerland & 4 \\
\hline Poland & 45 & the Russian Federa- & 4 \\
tion & Belgium & 3 \\
\hline USA & 34 & Finland & 3 \\
\hline Germany & 23 & Canada & 2 \\
\hline Sweden & 11 & Ukraine & 1 \\
\hline France & 10 & Japan & 1 \\
\hline Austria & 6 & & \\
\hline
\end{tabular}

Analysis shows that almost all of Stanislav Zhukovsky's TOP paintings are in private collections and do not have a full description. As a result, the general art criticism community not only cannot see these paintings, but also analyze their artistic value. Art museums do not participate in auctions, although, judging by the prices, the artist's paintings are quite affordable for purchase. Today it makes sense to unite the efforts of art critics, museum workers and patrons of art in order to open Stanislav Zhukovsky to a wide circle of art lovers, to give a well-deserved assessment of the talent of the great Polish artist.

\section{REFERENCES}

1. Gorelov M.I. Stanislav Yulianovich Zhukovsky. Life and work 1875 - 1944. - Moscow: Art, 1982.- 272 p.

2. Stankevich, N. I. Stanislav Yulianovich Zhukovsky / N. I. Stankevich. - L.: Artist of the RSFSR, 1974.- 48 p.

3. Lapshin V. P. Zhukovsky S. Yu. Album. The author of the text and compiler is V.P. Lapshin. - Moscow: Fine Art, 1972.- 64 p.

4. Niewiadomski E. Malarstwo polskie XIX - XX wieku. - Warszawa, 1923. - P. 252.

5. Janski J. Art-banking w Polsce - to fikcja? Available at:

https://www.karierawfinansach.pl/artykul/ wiadomości / art-banking-w-polsce-to-fikcja (Accessed 18 October 2020)

6. Exact information about food prices in Russia in the 19th century. Available at: https://yakapitalist.ru/finansy/stoimost-produktov-v19-veke/ (Accessed 18 October 2020)

7. Average salary in Poland in 2019 Available at: https://www.rupoland.com/finances/76-mid-salary-poland (Accessed 25 October 2020) 